\title{
Growth, chemical composition and soil properties of Tipuana speciosa (Benth.) Kuntze seedlings irrigated with sewage effluent
}

\author{
Hayssam M. Ali • Mohamed H. Khamis • \\ Fatma A. Hassan
}

Received: 25 March 2011/ Accepted: 2 February 2012/Published online: 6 March 2012

(C) The Author(s) 2012. This article is published with open access at Springerlink.com

\begin{abstract}
This study was carried out at a greenhouse of Sabahia Horticulture Research Station, Alexandria, Egypt, to study the effect of sewage effluent on the growth and chemical composition of Tipuana speciosa (Benth.) Kuntze seedlings as well as on soil properties for three stages. The irrigation treatments were primary-treated wastewater and secondary-treated wastewater, in addition to tap water as control. Therefore, the treated wastewater was taken from oxidation ponds of New Borg El-Arab City. Results of these study revealed that the primary effluent treatment explored the highest significant values for vegetative growth and biomass, compared to the other treatments. In addition, the higher significant concentration and uptake of chemical composition in different plant parts were obtained from the primary effluent treatment during the three stages of irrigation. It was found that the concentration of heavy metals in either plant or soil was below as compared to the worldrecommended levels. These findings suggested that the use of sewage effluent in irrigating $T$. speciosa seedlings grown in calcareous soil was beneficial for the improvement of soil properties and production of timber trees, and also important for the safe manner of disposal of wastewater.
\end{abstract}

Keywords Irrigation - Sewage effluent - Vegetative growth $\cdot$ Chemical composition - Soil properties . Heavy metals - Tipuana speciosa (Benth.) Kuntze

H. M. Ali ( $\bowtie)$

Botany and Microbiology Department, College of Science, King Saud University, P.O. Box 2455, Riyadh 11451, Saudi Arabia e-mail: Hayssam77@ hotmail.com

H. M. Ali - M. H. Khamis - F. A. Hassan

Timber Trees Research Department, Sabahia Horticulture

Research Station, Horticulture Research Institute,

Agriculture Research Center, Alexandria, Egypt

\section{Introduction}

In many arid and semi-arid countries, water is becoming a scarce resource which must be used economically and effectively to promote further development. At the same time, with the population expanding at a high rate, the need for increased agricultural production is apparent.

Many countries have included wastewater reuse as an important dimension of water resources planning. Many communities have practised excreta reuse and effluent reuse for hundreds of years and it is part of their culture. The quality of river water used in some irrigation projects is such that reuse of human and animal waste is continually taking place, albeit in an uncontrolled fashion. Rapid increases in population and industrial growth have led to more treatments of wastewater in order to reduce pollution and protect receiving waters. It is then a natural progression to seek direct reuse of this treated effluent for lower grade purposes, such as irrigation.

Irrigation of forest species, used for fuel and timber, with wastewater is an approach that helps overcome health hazards associated with sewage farming. Growing green belts around the cities with forest trees under wastewater irrigation also helps in renewal of the ecological balance and improves environmental quality by self-treatment of wastewater through the application and forest irrigation.

The use of primary and secondary effluents in irrigation can improve the quality of soil and plant growth, because they are considered as natural conditioners through their nutrient elements and organic matter. However, the direct application of wastewater on agricultural land is limited by the extent of contamination with heavy metals, toxic organic chemicals and pathogens (Salem et al. 2000; Sebastiani et al. 2004; EL-Sayed 2005; Singh and Bhati 2005). 
Tipuana speciosa (Benth.) Kuntze (rosewood) is one of the true mahoganies. It is a large tropical tree with heavy-weight woods and, also, is one of the most valuable timber trees. Rosewood is extremely strong, hard, stable and decay resistant. This wood is used for decorative veneers, interiors and pattern making, as well as in shipbuilding and interiors of fine boats.

As available data on the use of sewage for irrigating forest trees of Egypt are limited, this study aims to explore the effects of irrigation with sewage effluent on the vegetative growth and chemical composition of T. speciosa, as well as the chemical properties of the planted soil.

\section{Materials and methods}

This study was carried out at a greenhouse in the nursery of Timber Trees Research Department, Sabahia Horticulture Research Station, Alexandria, Egypt, to investigate the effects of sewage effluent on vegetative growth, chemical composition of Tipuana speciosa (Benth.) Kuntze and chemical properties of planted soil throughout three stages (8, 16 and 24 months after treatment).

One-year-old seedlings of $T$. speciosa (Benth.) Kuntze were used for this study so that they averaged $28 \mathrm{~cm}$ in height and $3.6 \mathrm{~mm}$ in diameter (at $5 \mathrm{~cm}$ from the soil surface). Moreover, two types of sewage effluents were used to irrigate the seedlings, after 1 month from planting: primary- and secondary-treated wastewaters that were taken from oxidation ponds of a sewage effluent treatment station in New Borg El-Arab City, Alexandria. The sewage effluent contains a mixture of domestic and industrial sources. On the other hand, tap water was used as control treatment. The analysis of the used water in irrigation is shown in Table 1; Table 2 demonstrates the physical and chemical analysis of the planting soil. The tree seedlings were irrigated to field capacity to standardize the irrigation rate for the three treatments.

Trace elements in samples were analyzed using atomic absorption spectrophotometer. Soluble $\mathrm{N}$ was determined by the Kjeldahl method (Page et al. 1982). Soluble P was determined by the ascorbic acid molybdenum blue method (Watanabe and Olsen 1965). Dissolved oxygen (DO) was determined by the azide modification of Winkler method and chemical oxygen demand (COD) by dichromate oxidation method. Five-day biochemical oxygen demand $\left(\mathrm{BOD}_{5}\right)$ was determined from the amount of oxygen lost after incubation for 5 days in the dark at $20^{\circ} \mathrm{C}$ (APHA 1995).

At the end of each stage (8, 16 and 24 months), three seedlings from each treatment were chosen randomly to measure the parameters of vegetative growth and chemical composition of leaves, shoots and root. Otherwise, at the end of each stage, soil samples were taken from each treatment to measure their chemical properties according to Page et al. (1982). Heavy metals (Cd, Fe, Ni, Pb, Cu, Mn
Table 1 Average of water composition used in irrigation treatments in the experiment

\begin{tabular}{|c|c|c|c|c|}
\hline \multirow[t]{2}{*}{ Parameter } & \multicolumn{2}{|c|}{ Sewage effluent } & \multirow[t]{2}{*}{ Tap water } & \multirow{2}{*}{$\begin{array}{l}\text { Limits of } \\
\text { wastewater } \\
\text { for agric. reuse } \\
\text { (FAO 1992) }\end{array}$} \\
\hline & $\begin{array}{l}\text { Primary } \\
\text { treatment }\end{array}$ & $\begin{array}{l}\text { Secondary } \\
\text { treatment }\end{array}$ & & \\
\hline $\mathrm{pH}$ & 6.82 & 7.56 & 6.80 & $6.50-8.40$ \\
\hline E.C ds/m & 1.60 & 2.96 & 0.68 & $3.00-7.00$ \\
\hline \multicolumn{5}{|c|}{ Soluble cations (meq/L) } \\
\hline $\mathrm{Ca}^{2+}$ & 2.83 & 3.34 & 1.10 & - \\
\hline $\mathrm{Mg}^{2+}$ & 2.21 & 3.31 & 1.90 & - \\
\hline $\mathrm{K}^{+}$ & 0.23 & 0.26 & 0.20 & - \\
\hline $\mathrm{Na}^{+}$ & 11.95 & 16.75 & 2.60 & - \\
\hline \multicolumn{5}{|c|}{ Soluble anions $(\mathrm{meq} / \mathrm{L})$} \\
\hline $\mathrm{CO}_{3}^{-}$ & - & - & - & - \\
\hline $\mathrm{HCO}_{3}^{-}$ & 4.63 & 5.00 & 2.00 & $1.50-8.50$ \\
\hline $\mathrm{Cl}^{-}$ & 8.41 & 9.34 & 3.80 & - \\
\hline DO (mg/L) & 0.00 & 2.90 & - & - \\
\hline BOD5 (mg/L) & 220 & 100 & - & $40-500$ \\
\hline COD (mg/L) & 402 & 311 & - & $80-600$ \\
\hline TSS (mg/L) & 1024 & 1894 & - & - \\
\hline Soluble N (ppm) & 1.25 & 1.08 & 0.26 & - \\
\hline Soluble P (ppm) & 0.38 & 0.33 & 0.01 & - \\
\hline \multicolumn{5}{|c|}{ Total heavy metals (ppm) } \\
\hline $\mathrm{Cd}$ & 0.02 & 0.01 & 0.007 & 0.01 \\
\hline $\mathrm{Cu}$ & 0.14 & 0.19 & 0.009 & 0.20 \\
\hline Mn & 0.06 & 0.05 & 0.014 & 0.20 \\
\hline $\mathrm{Ni}$ & 0.02 & 0.01 & 0.002 & 0.20 \\
\hline $\mathrm{Pb}$ & 0.25 & 0.24 & 0.02 & 5.00 \\
\hline $\mathrm{Zn}$ & 1.86 & 1.07 & 0.09 & 2.00 \\
\hline $\mathrm{Fe}$ & 12.5 & 8.60 & 0.26 & 5.00 \\
\hline
\end{tabular}

and $\mathrm{Zn}$ ) were extracted by DTPA and then measured in solution by atomic absorption spectrophotometer (Lindsay and Norvell 1978).

Statistical analysis

The design of the experiment was completely randomized. The three treatments were replicated three times, and each repetition contained four seedlings. The mean values among all treatments were compared by Duncan's multiple range test, according to Snedecor and Cochran (1968).

\section{Results and discussion}

Vegetative growth

Significantly, the application of sewage effluent treatments increased all vegetative growth parameters compared with tap water treatment (Table 3). Primary effluent significantly 
Table 2 Physical and chemical analyses of soil

\begin{tabular}{|c|c|}
\hline Parameter & Mean \\
\hline \multicolumn{2}{|c|}{ Practical size distribution } \\
\hline Sand $(\%)$ & 70.00 \\
\hline Silt $(\%)$ & 20.00 \\
\hline Clay $(\%)$ & 10.00 \\
\hline Soil texture & Sandy loam \\
\hline $\mathrm{pH}$ & 8.31 \\
\hline E.C (ds/m) & 2.42 \\
\hline $\mathrm{CaCO}_{3}(\%)$ & 32.04 \\
\hline Organic matter $(\%)$ & 0.62 \\
\hline \multicolumn{2}{|c|}{ Soluble cations (meq/L) } \\
\hline $\mathrm{Ca}^{2+}$ & 5.58 \\
\hline $\mathrm{Mg}^{2+}$ & 6.15 \\
\hline $\mathrm{Na}^{+}$ & 14.25 \\
\hline $\mathrm{K}^{+}$ & 0.74 \\
\hline \multicolumn{2}{|c|}{ Soluble anions (meq/L) } \\
\hline $\mathrm{CO}_{3}^{-}$ & - \\
\hline $\mathrm{HCO}_{3}{ }^{-}$ & 8.30 \\
\hline $\mathrm{Cl}^{-}$ & 9.10 \\
\hline $\mathrm{SO}_{4}^{-}$ & 9.42 \\
\hline Available P (ppm) & 4.60 \\
\hline Available N (ppm) & 7.28 \\
\hline \multicolumn{2}{|c|}{ DTPA—extractable heavy metals (ppm) } \\
\hline $\mathrm{Cd}$ & 0.00 \\
\hline $\mathrm{Cu}$ & 0.77 \\
\hline $\mathrm{Mn}$ & 1.44 \\
\hline $\mathrm{Ni}$ & 1.11 \\
\hline $\mathrm{Pb}$ & 2.13 \\
\hline $\mathrm{Zn}$ & 0.89 \\
\hline $\mathrm{Fe}$ & 3.10 \\
\hline
\end{tabular}

increased vegetative growth parameters by around 1.5 -fold more than secondary effluent treatment throughout the three stages ( 8,16 and 24 months).

The plant heights of $T$. speciosa seedlings irrigated with the primary effluent increased by $69.34,64.96$ and $60.00 \%$ more than those with tap water at the 8-, 16- and 24-month stages, respectively, whereas for the seedlings irrigated with secondary effluent, they were $30.19,33.62$ and $43.20 \%$ more than those with tap water treatment through the three stages, respectively. Consequently, plant heights of the seedlings that were irrigated with primary effluent increased by 1.3-, 1.2- and 1.1-fold after 8, 16 and 24 months, respectively, more than the seedlings irrigated by the secondary effluent.

The same was observed in the stem diameters after 8,16 and 24 months for the seedling that were irrigated with the primary effluent: they were thicker by $132.14,66.86$ and $84.28 \%$, respectively, more than those with tap water treatment (Table 3). Furthermore, secondary effluent
Table 3 Effect of sewage effluent on vegetative growth parameters and leaves biomass of Tipuana speciosa at the three stages

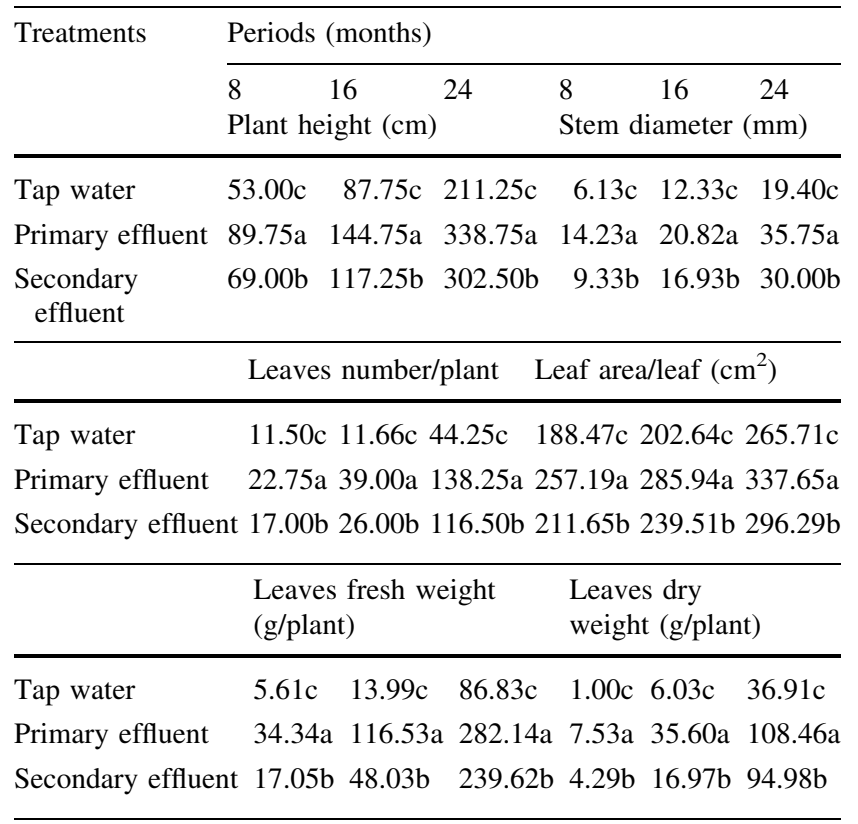

Mean followed by a similar letter within a column is not significantly different at the 0.05 level probability by Duncan's multiple range test

increased stem diameter of the seedlings by $52.20,37.31$ and $54.64 \%$ more than control for the 8,16 and 24 months stages, respectively. On the other hand, the stem diameters of the seedlings that were irrigated with the primary effluent increased by 1.5 -fold after 8 months and 1.2-fold after both 16 and 24 months more than the seedlings irrigated by the secondary effluent.

The leaf numbers per plant of $T$. speciosa were counted when the seedlings were irrigated with the primary effluent and were recorded as $97.83,234.48$ and $212.43 \%$ more than those with tap water for the 8-, 16- and 24-month stages, respectively, while the seedlings that were irrigated with secondary effluent significantly recorded 47.83, 122.98 and $163.28 \%$ more than with tap water for the 8-, 16- and 24-month stages, respectively. It was clear that leaf numbers of the seedlings that were irrigated with primary effluent were 1.3-, 1.5- and 1.2-fold more than those irrigated with the secondary effluent.

Tipuana speciosa seedlings that were irrigated with the primary effluent significantly had the largest leaf area (36.46, 41.11 and $31.53 \%$ for 8,16 and 24 months, respectively) more than control, whereas the leaf areas of the seedlings irrigated with the secondary effluent were $12.30,18.19$ and $15.42 \%$ more than the control for the three stages, respectively. Data in Table 3 indicate that the leaf area of the seedlings irrigated with the primary effluent was increased by 1.2 -fold after both 8 and 16 months and 1.1-fold after 24 months more than the seedlings irrigated by the secondary effluent. 
Table 4 Effect of sewage effluent on the shoots and roots biomass, shoot/root ratio and root length of Tipuana speciosa at three stages

\begin{tabular}{|c|c|c|c|c|c|c|}
\hline \multirow[t]{3}{*}{ Treatments } & \multicolumn{6}{|c|}{ Periods (months) } \\
\hline & 8 & 16 & 24 & 8 & 16 & 24 \\
\hline & \multicolumn{3}{|c|}{ Shoots fresh weight (g/plant) } & \multicolumn{3}{|c|}{ Shoots dry weight (g/plant) } \\
\hline Tap water & $9.06 \mathrm{c}$ & $37.38 \mathrm{c}$ & $162.62 \mathrm{c}$ & $1.71 \mathrm{c}$ & $12.11 \mathrm{c}$ & $82.03 c$ \\
\hline Primary effluent & $50.33 \mathrm{a}$ & $192.75 a$ & $659.75 a$ & $17.27 \mathrm{a}$ & $88.35 \mathrm{a}$ & $343.00 \mathrm{a}$ \\
\hline \multirow[t]{2}{*}{ Secondary effluent } & $28.80 \mathrm{~b}$ & $98.34 \mathrm{~b}$ & $472.28 b$ & $7.18 b$ & $43.03 b$ & $238.44 b$ \\
\hline & \multicolumn{3}{|c|}{ Roots fresh weight (g/plant) } & \multicolumn{3}{|c|}{ Roots dry weight (g/plant) } \\
\hline Tap water & $14.33 \mathrm{c}$ & $18.97 \mathrm{c}$ & $72.78 \mathrm{c}$ & $3.69 \mathrm{c}$ & $8.32 \mathrm{c}$ & $39.73 \mathrm{c}$ \\
\hline Primary effluent & $50.31 \mathrm{a}$ & $83.76 \mathrm{a}$ & $243.82 \mathrm{a}$ & $19.37 \mathrm{a}$ & $28.31 \mathrm{a}$ & $114.28 \mathrm{a}$ \\
\hline Secondary effluent & $32.19 \mathrm{~b}$ & $45.93 b$ & $152.93 b$ & $7.86 \mathrm{~b}$ & $16.37 \mathrm{~b}$ & $73.40 \mathrm{~b}$ \\
\hline
\end{tabular}

Root length $(\mathrm{cm})$

\begin{tabular}{llll}
\hline Tap water & $85.75 \mathrm{a}$ & $100.50 \mathrm{a}$ & $120.50 \mathrm{a}$ \\
Primary effluent & $80.75 \mathrm{a}$ & $91.75 \mathrm{az}$ & $117.00 \mathrm{a}$ \\
Secondary effluent & $72.00 \mathrm{a}$ & $85.50 \mathrm{a}$ & $108.75 \mathrm{a}$
\end{tabular}

Mean followed by a similar letter within a column is not significantly different at the 0.05 level probability by Duncan's Multiple Range Test

The fresh weights of the leaves of the T. speciosa seedlings irrigated with primary effluent were the heavier by $512.12,732.95$ and $224.93 \%$ more than those with tap water at the 8-, 16- and 24-month stages, respectively, while for the seedlings irrigated with the secondary effluent, they were 203.92, 243.32 and $175.96 \%$ more than those with tap water treatment through the same three stages, respectively. Consequently, leaves fresh weights of the seedlings that irrigated with primary effluent were folded by 2.0, 2.4 and 1.2 after 8 , 16 and 24 months, respectively, more than the seedlings irrigated by secondary effluent. Similar trend was observed in the leaves dry weights after 8, 16 and 24 months for the seedling that irrigated with primary effluent where they were heavier by $653.00,490.38$ and $193.85 \%$, respectively, more than tap water treatment (Table 3 ). In addition, secondary effluent increased leaves dry weights of the seedlings by $329.00,181.43$ and $157.33 \%$ more than control for 8,16 and 24 months stages, respectively. On the other hand, leaves dry weights of the seedlings that irrigated with primary effluent were folded by 1.8, 2.1 and 1.1 after 8,16 and 24 months more than the seedlings irrigated by secondary effluent.

Shoots fresh weights of $T$. speciosa seedlings which irrigated by primary effluent were the heaviest by $455.52,415.65$ and $305.70 \%$ more than tap water for 8, 16 and 24 months stages, respectively. While, they were $217.88,163.08$ and $190.42 \%$ more than tap water treatment throughout the same three stages, respectively, for the seedlings that irrigated with secondary effluent. Hence, shoots fresh weights of the seedlings which irrigated by primary effluent were folded by 1.7 , 2.0 and 1.4 after 8,16 and 24 months, respectively, more than the seedlings irrigated by secondary effluent. The dry weights of shoots had similar trend after 8,16 and 24 months for the seedling which irrigated by primary effluent where they were heavier by $915.88,629.56$ and $318.14 \%$, respectively, more than tap water treatment (Table 4). Also, secondary effluent increased shoots dry weights of the seedlings by 322.35 , 255.33 and $190.67 \%$ more than control for 8, 16 and 24 months stages, respectively. On the other hand, shoots dry weights of the seedlings that irrigated with primary effluent were folded by 2.4, 2.1 and 1.4 after 8,16 and 24 months more than the seedlings irrigated by secondary effluent.

These results explained by many investigators, who found that sewage effluent had stimulation effect on vegetative growth of trees, provided the soil with plant nutrients and organic matter as well as improved the physical properties of the soil, that reflected on the growth by enhancing either the cell elongation and division (Kaneker et al. 1993 on Acacia nilotica; Hassan Fatma et al. 2002 on Acacia saligna and Leucaena leucocephala; Berbec et al. 1999 on poplar; Guo and Sims 2000 on Eucalyptus globules; Abbaas 2002 on Casuarina glauca, Taxodium distichum and Populus nigra; Bhati and Singh 2003 on Eucalyptus camaldulensis; EL-Sayed 2005 on Ceratonia siliqua, A. saligna and Acacia stenophylla, and Singh and Bhati 2005 on Dalbergia sissoo).

\section{Root characteristics}

Table 4 exhibited that roots weights of $T$. speciosa had the same trend of the leaves and shoots along the three investigated stages (Table 4). Therefore, roots fresh 
weights of the seedlings that irrigated with primary effluent were the heaviest by $251.08,341.54$ and $235.01 \%$ more than tap water for 8,16 and 24 months stages, respectively. While, they were $124.63,142.12$ and $110.13 \%$ more than tap water treatment through the same three stages, respectively, for the seedlings that irrigated with secondary effluent. Hence, roots fresh weights of the seedlings that irrigated with primary effluent were folded by $1.6,1.8$ and 1.6 after 8,16 and 24 months, respectively, more than fresh roots of the seedlings irrigated by secondary effluent.

The same trend was detected in the roots dry weights after 8, 16 and 24 months for the seedling that irrigated with primary effluent where they were heavier by 424.93 , 240.26 and $187.64 \%$, respectively, more than tap water treatment (Table 4). Also, secondary effluent increased roots dry weights of the seedlings by $113.01,96.75$ and $84.75 \%$ more than control for 8,16 and 24 months stages, respectively. Further, roots dry weights of the seedlings that irrigated with primary effluent were folded by $2.5,1.7$ and 1.6 after 8,16 and 24 months more than dry roots of the seedlings irrigated by secondary effluent.

In contrast, secondary effluent treatment gave the shortest roots length $(16.03,14.93$ and $9.75 \%$ less than tap water treatment for 8,16 and 24 months stages, respectively). Consequently, it followed by primary sewage effluent treatment $(5.83,8.71$ and $2.90 \%$ less than tap water treatment for 8,16 and 24 months stages, respectively). This action could be explained by the accumulation of soluble salts and heavy metals in root zone, as a result of applying sewage effluent, which might adverse root elongation. This results are in harmony with these of Nessel et al. (1982) on Pond cypress, Hopmans et al. (1990) on E. camaldulensis and Pinus radiata, Gogate et al.(1995) on Tectona grandis, Hassan Fatma et al. (2002) on Albizzia lebbek, Taxodium distichum and T. speciosa and Ali et al. (2011) on Swietenia mahagoni.

Data of the root characteristics are in agreement with those of Sebastiani et al. (2004) on poplar and EL-Sayed (2005) on Ceratonia siliqua.

\section{Chemical composition}

Generally, irrigation with primary effluent gave the highest concentrations of $\mathrm{N}, \mathrm{P}, \mathrm{k}, \mathrm{Cd}, \mathrm{Ni}, \mathrm{Pb}$ and $\mathrm{Fe}$ in leaves, shoots and roots of $T$. speciosa followed by secondary effluent treatment (Tables 5, 6).

As well as, the concentrations of $\mathrm{N}, \mathrm{P}$ and $\mathrm{K}$ in leaves were much higher than that of shoots and roots. The increase of $\mathrm{N}, \mathrm{P}, \mathrm{K}, \mathrm{Cd}, \mathrm{Ni}, \mathrm{Pb}$ and $\mathrm{Fe}$ in plant parts might be attributed to increasing them in the occupancy root zone from applying sewage effluents, which reflected on their uptake by roots.

These results are agreed with the findings of Singh and Bhati (2005) who found that concentrations of N, P and K were greater in foliage compared to the other plant parts. In contrary heavy metals $(\mathrm{Cd}, \mathrm{Ni}, \mathrm{Pb}$ and $\mathrm{Fe})$ tended to be accumulated in root rather than in both leaves and shoots with few exceptions. When irrigation stage enlarged from 8

Table 5 Effect of sewage effluent on N, P and K percentage and total uptake of leaves (L), shoots (S) and roots (R) of Tipuana speciosa at three stages

\begin{tabular}{|c|c|c|c|c|c|c|c|c|c|c|c|c|}
\hline \multirow[t]{3}{*}{ Treatments } & \multicolumn{12}{|c|}{ Periods (months) } \\
\hline & \multicolumn{3}{|l|}{8} & \multicolumn{3}{|l|}{16} & \multicolumn{3}{|l|}{24} & \multirow[b]{2}{*}{ Total $\mathrm{N}$} & \multirow[b]{2}{*}{ take $(g$} & \multirow{2}{*}{$\begin{array}{l}24 \\
\left.t^{-1}\right)\end{array}$} \\
\hline & \multicolumn{9}{|l|}{$\mathrm{N}(\%)$} & & & \\
\hline Tap water & $0.92 \mathrm{c}$ & $0.52 \mathrm{c}$ & $0.57 \mathrm{c}$ & $0.94 \mathrm{c}$ & $0.68 \mathrm{c}$ & $0.66 \mathrm{c}$ & $0.59 \mathrm{~b}$ & $0.59 \mathrm{c}$ & $0.54 b$ & $0.04 \mathrm{c}$ & $0.19 \mathrm{c}$ & $0.92 \mathrm{c}$ \\
\hline Primary effluent & $2.09 \mathrm{a}$ & $1.49 \mathrm{a}$ & $1.51 \mathrm{a}$ & $1.82 \mathrm{a}$ & $1.49 \mathrm{a}$ & $1.23 \mathrm{a}$ & $1.92 \mathrm{a}$ & $1.14 \mathrm{a}$ & $1.15 \mathrm{a}$ & $0.71 \mathrm{a}$ & $2.31 \mathrm{a}$ & $7.31 \mathrm{a}$ \\
\hline \multirow[t]{2}{*}{ Secondary effluent } & $1.77 \mathrm{~b}$ & $1.24 \mathrm{~b}$ & $1.24 \mathrm{~b}$ & $1.22 \mathrm{~b}$ & $0.88 b$ & $0.96 b$ & $1.57 \mathrm{a}$ & $0.93 b$ & $0.95 \mathrm{a}$ & $0.26 b$ & $0.74 b$ & $4.41 \mathrm{~b}$ \\
\hline & \multicolumn{9}{|l|}{$\mathrm{P}(\%)$} & \multicolumn{3}{|c|}{ Total $\mathrm{P}$ uptake (g/plant) } \\
\hline Tap water & $0.34 \mathrm{~b}$ & $0.32 \mathrm{c}$ & $0.26 \mathrm{c}$ & $0.22 b$ & $0.17 b$ & $0.19 b$ & $0.21 \mathrm{~b}$ & $0.18 \mathrm{~b}$ & $0.22 \mathrm{c}$ & $0.03 c$ & $0.05 \mathrm{c}$ & $0.31 \mathrm{c}$ \\
\hline Primary effluent & $0.52 \mathrm{a}$ & $0.54 \mathrm{a}$ & $0.57 \mathrm{a}$ & $0.46 \mathrm{a}$ & $0.22 \mathrm{a}$ & $0.30 \mathrm{a}$ & $0.76 \mathrm{a}$ & $0.52 \mathrm{a}$ & $0.54 \mathrm{a}$ & $0.24 \mathrm{a}$ & $0.44 \mathrm{a}$ & $3.23 \mathrm{a}$ \\
\hline \multirow[t]{2}{*}{ Secondary effluent } & $0.47 \mathrm{a}$ & $0.41 b$ & $0.45 b$ & $0.37 \mathrm{a}$ & $0.20 \mathrm{ab}$ & $0.19 b$ & $0.45 b$ & $0.36 \mathrm{a}$ & $0.40 \mathrm{~b}$ & $0.08 b$ & $0.18 b$ & $1.58 \mathrm{~b}$ \\
\hline & \multicolumn{9}{|l|}{$\mathrm{K}(\%)$} & \multicolumn{3}{|c|}{ Total K uptake (g/plant) } \\
\hline Tap water & $0.87 b$ & $0.75 b$ & $0.42 \mathrm{c}$ & $0.79 b$ & $0.63 b$ & $0.43 \mathrm{c}$ & $0.70 \mathrm{~b}$ & $0.48 b$ & $0.46 \mathrm{c}$ & $0.04 \mathrm{c}$ & $0.16 \mathrm{c}$ & $0.83 \mathrm{c}$ \\
\hline Primary effluent & $1.39 \mathrm{a}$ & $0.87 \mathrm{a}$ & $0.70 \mathrm{a}$ & $1.16 \mathrm{a}$ & $0.80 \mathrm{a}$ & $0.76 \mathrm{a}$ & $1.23 \mathrm{a}$ & $0.83 \mathrm{a}$ & $0.73 \mathrm{a}$ & $0.39 \mathrm{a}$ & $1.33 \mathrm{a}$ & $5.02 \mathrm{a}$ \\
\hline Secondary effluent & $0.97 \mathrm{~b}$ & $0.79 \mathrm{~b}$ & $0.56 \mathrm{~b}$ & 0.90 & $0.73 \mathrm{ab}$ & $0.58 \mathrm{~b}$ & $0.95 b$ & $0.57 \mathrm{~b}$ & $0.60 \mathrm{~b}$ & $0.14 b$ & $0.56 \mathrm{~b}$ & $2.70 \mathrm{~b}$ \\
\hline
\end{tabular}

Mean followed by a similar letter within a column is not significantly different at the 0.05 level probability by Duncan's Multiple Range Test 
Table 6 Effect of sewage effluent on $\mathrm{Cd}, \mathrm{Ni}, \mathrm{Pb}$ and $\mathrm{Fe}$ percentage and total uptake of leaves (L), shoots (S) and roots (R) of Tipuana speciosa at three stages

\begin{tabular}{|c|c|c|c|c|c|c|c|c|c|c|c|c|}
\hline \multirow[t]{4}{*}{ Treatments } & \multicolumn{12}{|c|}{ Periods (months) } \\
\hline & \multicolumn{3}{|l|}{8} & \multicolumn{3}{|l|}{16} & \multicolumn{3}{|l|}{24} & \multirow[t]{2}{*}{8} & \multirow[t]{2}{*}{16} & \multirow[t]{2}{*}{24} \\
\hline & $\mathrm{L}$ & $\mathrm{S}$ & $\mathrm{R}$ & $\mathrm{L}$ & $\mathrm{S}$ & $\mathrm{R}$ & $\mathrm{L}$ & $\mathrm{S}$ & $\mathrm{R}$ & & & \\
\hline & \multicolumn{9}{|c|}{$\mathrm{Cd}(\mathrm{ppm})$} & \multicolumn{3}{|c|}{ Total Cd uptake (mg/plant) } \\
\hline Tap water & $0.27 \mathrm{~b}$ & $0.30 \mathrm{c}$ & $0.57 \mathrm{c}$ & $0.05 b$ & $0.03 b$ & $0.06 \mathrm{c}$ & $0.06 b$ & $0.21 b$ & $0.22 b$ & $0.01 \mathrm{c}$ & $0.01 b$ & $0.03 \mathrm{c}$ \\
\hline Primary effluent & $2.83 \mathrm{a}$ & $2.23 \mathrm{a}$ & $3.37 \mathrm{a}$ & $2.60 \mathrm{a}$ & $1.93 \mathrm{a}$ & $2.70 \mathrm{a}$ & $1.96 \mathrm{a}$ & $1.70 \mathrm{a}$ & $1.90 \mathrm{a}$ & $0.13 \mathrm{a}$ & $0.34 \mathrm{a}$ & $1.01 \mathrm{a}$ \\
\hline \multirow[t]{2}{*}{ Secondary effluent } & $0.90 \mathrm{~b}$ & $1.10 \mathrm{~b}$ & $1.87 \mathrm{~b}$ & $0.80 \mathrm{~b}$ & $1.00 \mathrm{ab}$ & $1.06 \mathrm{~b}$ & $0.56 b$ & $1.33 \mathrm{a}$ & $0.90 \mathrm{~b}$ & $0.03 b$ & $0.07 \mathrm{~b}$ & $0.44 b$ \\
\hline & \multicolumn{9}{|c|}{$\mathrm{Ni}(\mathrm{ppm})$} & \multicolumn{3}{|c|}{ Total Ni uptake (mg/plant) } \\
\hline Tap water & $12.33 \mathrm{c}$ & $8.67 \mathrm{~b}$ & $15.33 \mathrm{c}$ & $14.33 \mathrm{c}$ & $11.33 \mathrm{c}$ & $11.67 \mathrm{c}$ & $10.33 \mathrm{c}$ & $9.33 b$ & $11.66 \mathrm{c}$ & $0.08 \mathrm{c}$ & $0.32 \mathrm{c}$ & $1.61 \mathrm{c}$ \\
\hline Primary effluent & $43.33 \mathrm{a}$ & $37.33 \mathrm{a}$ & $46.67 \mathrm{a}$ & $134.33 \mathrm{a}$ & $117.00 \mathrm{a}$ & $136.00 \mathrm{a}$ & $151.33 \mathrm{a}$ & $126.33 \mathrm{a}$ & $159.00 \mathrm{a}$ & $1.87 \mathrm{a}$ & $18.97 \mathrm{a}$ & $77.91 \mathrm{a}$ \\
\hline \multirow[t]{2}{*}{ Secondary effluent } & $31.67 \mathrm{~b}$ & $28.33 \mathrm{a}$ & $35.33 b$ & $98.33 b$ & $95.66 \mathrm{~b}$ & $92.67 \mathrm{~b}$ & $114.33 b$ & $102.33 \mathrm{a}$ & $119.66 b$ & $0.62 b$ & $7.30 \mathrm{~b}$ & $44.04 \mathrm{~b}$ \\
\hline & \multicolumn{9}{|c|}{$\mathrm{Pb}(\mathrm{ppm})$} & \multicolumn{3}{|c|}{ Total $\mathrm{Pb}$ uptake (mg/plant) } \\
\hline Tap water & $38.00 \mathrm{c}$ & $31.00 \mathrm{c}$ & $39.00 \mathrm{c}$ & $43.66 \mathrm{c}$ & $36.33 \mathrm{c}$ & $36.66 \mathrm{c}$ & $42.00 \mathrm{c}$ & $24.33 c$ & $31.67 \mathrm{~b}$ & $0.23 \mathrm{c}$ & $1.01 \mathrm{c}$ & $4.80 \mathrm{c}$ \\
\hline Primary effluent & $122.33 \mathrm{a}$ & $114.33 \mathrm{a}$ & $170.00 \mathrm{a}$ & $131.33 \mathrm{a}$ & $114.33 \mathrm{a}$ & $147.00 \mathrm{a}$ & $150.67 \mathrm{a}$ & $135.66 \mathrm{a}$ & $155.33 \mathrm{a}$ & $6.19 a$ & $18.94 \mathrm{a}$ & $80.62 \mathrm{a}$ \\
\hline \multirow[t]{2}{*}{ Secondary effluent } & $90.67 b$ & $95.33 b$ & $111.67 \mathrm{~b}$ & $105.66 \mathrm{~b}$ & $84.67 \mathrm{~b}$ & $81.33 b$ & $102.33 b$ & $77.33 b$ & $162.67 \mathrm{a}$ & $1.95 \mathrm{~b}$ & $6.77 \mathrm{~b}$ & $40.10 \mathrm{~b}$ \\
\hline & \multicolumn{9}{|c|}{$\mathrm{Fe}(\mathrm{ppm})$} & \multicolumn{3}{|c|}{ Total Fe uptake (mg/plant) } \\
\hline Tap water & $195.67 \mathrm{c}$ & $147.67 \mathrm{c}$ & $246.67 b$ & $148.67 \mathrm{c}$ & $95.33 b$ & $130.00 \mathrm{c}$ & $106.67 \mathrm{c}$ & $93.33 \mathrm{c}$ & $111.67 \mathrm{c}$ & $1.36 \mathrm{~b}$ & $3.13 \mathrm{c}$ & $16.03 \mathrm{c}$ \\
\hline Primary effluent & $405.00 \mathrm{a}$ & $398.67 \mathrm{a}$ & $530.00 \mathrm{a}$ & $356.67 \mathrm{a}$ & $323.33 a$ & $370.00 \mathrm{a}$ & $359.33 \mathrm{a}$ & $303.33 \mathrm{a}$ & $346.67 \mathrm{a}$ & $20.26 \mathrm{a}$ & $51.74 \mathrm{a}$ & $182.63 \mathrm{a}$ \\
\hline Secondary effluent & $232.33 b$ & $242.33 b$ & $320.00 \mathrm{~b}$ & $223.33 b$ & $174.33 b$ & $240.00 \mathrm{~b}$ & $280.00 \mathrm{~b}$ & $213.33 b$ & $250.00 \mathrm{~b}$ & $5.25 \mathrm{~b}$ & $15.22 b$ & $95.81 b$ \\
\hline
\end{tabular}

Mean followed by a similar letter within a column is not significantly different at the 0.05 level probability by Duncan's Multiple Range Test

to 24 months, the uptakes of $\mathrm{N}, \mathrm{P}, \mathrm{K}, \mathrm{Cd}, \mathrm{Ni}, \mathrm{Pb}$ and $\mathrm{Fe}$ in the whole plant were increased due to enormity increase of vegetative growth. Similarly, EL-Sayed (2005) found that irrigation with secondary effluent increased $\mathrm{N}, \mathrm{P}, \mathrm{K}, \mathrm{Ca}$, $\mathrm{Mg}, \mathrm{Na}, \mathrm{Fe}, \mathrm{Zn}, \mathrm{Mn}, \mathrm{Cu}, \mathrm{Pb}, \mathrm{Cd}, \mathrm{Cr}$ and $\mathrm{Ni}$ in leaves, stems and roots of Ceratonia siliqua, A. saligna and A. stenophylla compared with tap water.

After 24 months, the magnitude of increase of heavy metals in the whole plant due to primary effluent treatment ranged from 2 to 9 times more than tap water for $\mathrm{Cd}, \mathrm{Ni}, \mathrm{Pb}$ and $\mathrm{Fe}$.

\section{Soil characteristics}

Data in Table 7 revealed that soil salinity in terms of electrical conductivity of saturated paste (EC), $\mathrm{CaCO}_{3}(\%)$, organic matter $(\%)$ and soluble anions and cations were influenced by both primary and secondary effluent treatment. Where, $\mathrm{pH}$ value slightly changed by irrigation with sewage effluent. EC values of soil treated with sewage effluent were related to $\mathrm{EC}$ values of irrigation water treatment therefore, EC of soil treated with tap water was decreased to 1.50 and $1.44 \mathrm{ds} / \mathrm{m}$ after 16 and 24 months of irrigation, respectively. While EC of soil treated with secondary and primary effluent were ranged between 2.76 and $3.48 \mathrm{ds} / \mathrm{m}$, respectively. However, the soluble cations and anions had the same trend of EC of soil except for $\mathrm{Ca}^{2+}$ and $\mathrm{SO}_{4}{ }^{-}$.

It is clear, from Table 7 , that irrigation with primary sewage effluent decreased the $\mathrm{CaCO}_{3}$ content from 32.26 to 31.04 and $29.15 \%$ for primary sewage effluent treatments after 8, 16 and 24 months, respectively, of irrigation stage. This is probably due to the fact that same $\mathrm{CaCO}_{3}$ was dissolved by the organic acids present in sewage and leached down in soil.

Furthermore, organic matter content increased with irrigation stage was extended from 8 to 16 then 24 months, with higher values for primary effluent compared with secondary (5, 14 and 22\% for former stages, respectively). Likewise, available $\mathrm{P}$ and $\mathrm{N}$ were also maximized more by primary effluent treatment compared to secondary effluent, while tape water gave the lowest values. In addition, it is clear that available $\mathrm{P}$ and $\mathrm{N}$ were accumulated more as stage of irrigation was extended from 8 to 16 then 24 months.

The results are agree with those of EL-Nennah et al. (1982) who found that use of sewage effluent in irrigation resulted in remarkable change of organic matter, available 
Table 7 Means of effect of sewage effluent on the soil properties of Tipuana speciosa plantation at three stages

\begin{tabular}{|c|c|c|c|c|c|c|c|c|c|}
\hline \multirow[t]{2}{*}{ Parameter } & \multicolumn{3}{|c|}{8 months } & \multicolumn{3}{|c|}{16 months } & \multicolumn{3}{|c|}{24 months } \\
\hline & $\begin{array}{l}\text { Tap } \\
\text { water }\end{array}$ & $\begin{array}{l}\text { Primary } \\
\text { effluent }\end{array}$ & $\begin{array}{l}\text { Secondary } \\
\text { effluent }\end{array}$ & $\begin{array}{l}\text { Tap } \\
\text { water }\end{array}$ & $\begin{array}{l}\text { Primary } \\
\text { effluent }\end{array}$ & $\begin{array}{l}\text { Secondary } \\
\text { effluent }\end{array}$ & $\begin{array}{l}\text { Tap } \\
\text { water }\end{array}$ & $\begin{array}{l}\text { Primary } \\
\text { effluent }\end{array}$ & $\begin{array}{l}\text { Secondary } \\
\text { effluent }\end{array}$ \\
\hline $\mathrm{pH}$ & 8.19 & 8.37 & 8.00 & 8.14 & 8.08 & 8.05 & 8.08 & 8.30 & 8.33 \\
\hline E.C (ds/m) & 2.51 & 2.60 & 3.14 & 1.50 & 2.76 & 3.40 & 1.44 & 2.95 & 3.48 \\
\hline $\mathrm{CaCO}_{3}(\%)$ & 30.26 & 32.26 & 31.15 & 28.48 & 31.04 & 30.26 & 27.26 & 29.15 & 30.15 \\
\hline Organic matter $(\%)$ & 0.64 & 0.89 & 0.84 & 0.67 & 1.08 & 0.94 & 0.67 & 1.20 & 0.98 \\
\hline $\mathrm{Ca}^{2+}(\mathrm{meq} / \mathrm{L})$ & 5.15 & 6.60 & 3.60 & 3.90 & 3.96 & 3.24 & 5.88 & 3.60 & 3.60 \\
\hline $\mathrm{Mg}^{2+}(\mathrm{meq} / \mathrm{L})$ & 4.40 & 4.65 & 2.18 & 3.13 & 3.52 & 3.39 & 4.22 & 3.96 & 3.00 \\
\hline $\mathrm{Na}^{+}(\mathrm{meq} / \mathrm{L})$ & 15.00 & 20.00 & 8.75 & 20.15 & 27.50 & 8.75 & 20.00 & 28.50 & 23.50 \\
\hline $\mathrm{K}^{+}(\mathrm{meq} / \mathrm{L})$ & 0.64 & 0.93 & 0.48 & 0.68 & 0.68 & 0.30 & 0.54 & 0.54 & 0.62 \\
\hline $\mathrm{CO}_{3}^{-}(\mathrm{meq} / \mathrm{L})$ & - & - & - & - & - & - & - & - & - \\
\hline $\mathrm{HCO}_{3}(\mathrm{meq} / \mathrm{L})$ & 2.32 & 3.98 & 3.36 & 2.98 & 3.65 & 3.98 & 4.81 & 5.81 & 5.15 \\
\hline $\mathrm{Cl}^{-}(\mathrm{meq} / \mathrm{L})$ & 12.59 & 18.51 & 5.10 & 15.94 & 18.20 & 6.92 & 14.01 & 19.11 & 18.20 \\
\hline $\mathrm{SO}_{4}^{-}(\mathrm{meq} / \mathrm{L})$ & 12.28 & 9.69 & 6.65 & 8.79 & 13.81 & 4.78 & 11.73 & 11.68 & 7.97 \\
\hline Available P (ppm) & 0.80 & 6.30 & 4.40 & 1.80 & 8.50 & 5.20 & 1.00 & 9.20 & 5.90 \\
\hline Available N (ppm) & 7.00 & 13.40 & 11.20 & 7.30 & 21.20 & 15.12 & 5.40 & 22.52 & 17.60 \\
\hline \multicolumn{10}{|c|}{ DTPA: extractable heavy metals (ppm) } \\
\hline $\mathrm{Cd}$ & - & 0.07 & 0.03 & - & 0.09 & 0.05 & - & 0.05 & 0.01 \\
\hline $\mathrm{Fe}$ & 3.10 & 2.98 & 3.64 & 3.28 & 3.40 & 3.44 & 3.10 & 3.12 & 4.66 \\
\hline $\mathrm{Ni}$ & 1.11 & 1.52 & 6.70 & 5.10 & 1.62 & 6.21 & 4.10 & 1.92 & 5.87 \\
\hline $\mathrm{Pb}$ & 2.13 & 2.50 & 7.96 & 6.87 & 2.42 & 6.50 & 6.54 & 2.21 & 6.32 \\
\hline $\mathrm{Cu}$ & 0.77 & 0.57 & 0.71 & 0.69 & 0.66 & 0.68 & 0.66 & 0.59 & 0.54 \\
\hline $\mathrm{Mn}$ & 1.44 & 1.44 & 1.8 & 1.62 & 0.81 & 0.72 & 0.66 & 0.66 & 0.52 \\
\hline $\mathrm{Zn}$ & 0.89 & 0.72 & 1.54 & 1.16 & 0.74 & 1.50 & 1.10 & 0.68 & 1.42 \\
\hline
\end{tabular}

$\mathrm{P}$ and total and soluble $\mathrm{N}$ which might have been added to soils upon irrigation.

\section{Extractable-heavy metals}

Results given in Table 7 show that DTPA-extractable Cd, $\mathrm{Cu}, \mathrm{Ni}$ and $\mathrm{Pb}$ increased as irrigation stage increased by sewage effluent treatments compared to tap water therefore, the primary effluent treatment gave the greater values $(0.05,0.59,1.92$ and 2.21 ppm for above-mentioned metals, respectively, after 24 months. Whereas, the response of extractable $\mathrm{Fe}, \mathrm{Mn}$ and $\mathrm{Zn}$ were not consistent for different sewage effluent treatments.

Many investigators stated that heavy metals accumulated in soil resulted from continuous irrigation with sewage effluent (EL-Nennah et al. 1982; Abulroos et al. 1996; Salem et al. 2000). This increment of heavy metals in soil and consequently in edible parts of field crop plant should be considered, which adversely affect human and animal health through the food chain. It would be great advantage to grow forest trees such as $T$. speciosa in heavily polluted areas or soil irrigated with sewage effluent without serious problems.
Open Access This article is distributed under the terms of the Creative Commons Attribution License which permits any use, distribution, and reproduction in any medium, provided the original author(s) and the source are credited.

\section{References}

Abbaas MM (2002) Effect of some heavy metals in the irrigation water on growth and chemical constituents of some timber trees. $\mathrm{PhD}$ Thesis, Faculty of Agriculture Cairo University

Abulroos SA, Holah ShSh, Badawy SH (1996) Background levels of some heavy metals in soil and corn in Egypt. Egypt J Soil Sci 36:83-95

Ali HM, EL-Mahrouk EM, Hassan Fatma A, EL-Tarawy MA (2011) Usage of sewage effluent in irrigation of some woody tree seedlings. Part 3: Swietenia mahagoni (L.) Jacq. Saudi J Biol Sci 18(2):201-207. doi:10.1016/j.sjbs.2010.08.001

APHA (1995) Standard methods for the examination of water and waste water, 19th edn. APHA-AWWA-WPCF, Washington DC, pp 4-85, 4-137

Berbec S, Szewczuk C, Sugier D (1999) The effect of irrigation with municipal sewage on the catching and growth rate of poplar trees. Folia Univ Agric 77:27-31

Bhati M, Singh G (2003) Growth and mineral accumulation in Eucalyptus camaldulensis seedlings irrigated with mixed industrial effluent. Bioresour Technol 88:221-228 
EL-Nennah M, EL-Kobbia T, Shehata A, EL-Gamal I (1982) Effect of irrigation loamy sand soil by sewage effluents on its content of some nutrients and heavy metals. Plant Soil 65:289-292

EL-Sayed NAA (2005) The impact of irrigation with treated wastewater effluent on soil bio-physicochemical properties and on growth and heavy metals content of some fodder trees grown on calcareous soil. PhD Thesis, Faculty of Agriculture, Tanta University

Gogate MG, Farooqui UM, Joshi VS (1995) Sewage water as potential for the tree growth: a study on teak (Tectona grandis) plantation. Indian For 121(6):472-481 (CAB.Abst. 1996, 0601478)

Guo LB, Sims REH (2000) Effect of meat works effluent irrigation on soil, tree biomass production and nutrient uptake in Eucalyptus globulus seedlings in growth cabinets. Bioresour Technol 72:243-251

Hassan Fatma A, EL-Juhany LI, EL-Settawy AA, Shehata MS (2002) Effects of irrigation with sewage effluent on the growth of some forest trees species, physical and chemical properties of the soil. In: Proceeding of the second conference "sustainable agricultural development" 8-10 May Fayoum, pp 300-311

Hopmans P, Stewart HT, Flinn DW, Hillman TJ (1990) Growth, biomass production and nutrient accumulation by seven tree species irrigated with municipal effluent at Wodonga, Australia. For Ecol Manag 30:203-211

Kaneker P, Kumbhojkar MS, Ghate V, Sarnaik S, Kelkar A (1993) Evaluation of Acacia nilotica (L.) DEL. and Casuarina equisetifolia forest for tolerance and growth on microbially treated dyestuff wastewater. Environ Pollut 81:47-50

Lindsay WL, Norvell WA (1978) Development of DTPA soil test for zinc, iron, manganese and copper. Soil Sci Soc Am J 42:421-428

Nessel JK, Ewel KC, Burnett M (1982) Wastewater enrichment increases mature Pond cypress growth rates. For Sci 28(2): 400-403

Page AL, Miller RH, Keeny DR (1982) Methods of soil analysis, part II. 2nd edn. Agronomy Monogr. ASA and SSSA, Medison

Salem MM, El-Amir S, Abdel-Aziz SM, Kandil MF, Mansour SF (2000) Effect of irrigation with sewage water on some chemical characteristics of soils and plant. Egypt J Soil Sci 40:49-59

Sebastiani L, Scebba F, Tognetti R (2004) Heavy metal accumulation and growth responses in poplar clones eridano (Populus deltoides $\times$ maximowiczii) and I-214 $(P . \times$ euramerilana $)$ exposed to industrial waste. Environ Exp Bot 52:79-88

Singh G, Bhati M (2005) Growth of Dalbergia sissoo in desert regions of western India using municipal effluent and the subsequent changes in soil and plant chemistry. Bioresour Technol 96:1019-1028

Snedecor GW, Cochran WG (1968) Statistical methods, 6th edn. The Iowa State University Press, Ames

Watanabe FS, Olsen SR (1965) Test of an ascorbic acid method for determining phosphorus in water and $\mathrm{NaHCO}_{3}$ extracts from soil. Soil Sci Soc Am J 22:677-678 